\title{
The determinants of FDI inflow in manufacturing sector of Malaysia
}

\begin{abstract}
The role of foreign direct investment (FDI) to create competition,technology transfer, reducing unemployment and generating productive economic growth is undeniable. Therefore, policy makers and economists seek to identify the factors that affect FDI in different sectors. Accordingly, this study investigated the determinants of FDI in manufacturing sector of Malaysia over the period from 2000 to 2009. Using quarterly data, this research found a positive and significant effect of domestic credit to private sector provided by banking system and development expenditure of government on FDI.Meanwhile, the effect of the global financial recession of 2007-2008 on FDI inflow to Malaysia was positive and significant, though due to this recession reduction of the world aggregate FDI reduced the growth of FDI inflow to the manufacturing sector of Malaysia. The effect of corruption on FDI's growth was also negative and significant
\end{abstract}

Keyword: Foreign direct investment; FDI; Domestic credit; Banking sector; Development expenditure; DEX; Corruption perception index; CPI; Economic recession 